\title{
Lassa fever infection from West Africa, dynamic and epidemiology of the virus on the population 1969-2019: a systematic review and meta-analysis
}

Roland Eric YESSINOU ( $\nabla$ eric.yessinou@uac.bj )

University of Abomey-Calavi https://orcid.org/0000-0003-4874-1820

Alain Richi Kamga Waladjo

Inter-State School of Veterinary Sciences and Medi

Dramou Ignace

Department of Biology, Faculty of Sciences, Gamal

Justin Adinsi

Universite d'Abomey-Calavi

Elsie Sangnidjo

Universite d'Abomey-Calavi

Razack Osse

University of Ketou

Alfred Dansou

Universite d'Abomey-Calavi

Safiou Adehan

University of Abomey-Calavi

Souaïbou FAROUGOU

University of Abomey-Calavi

Research article

Keywords: Lassa fever, Mastomys spp, prevalence, distribution, West Africa

Posted Date: July 1st, 2019

DOl: https://doi.org/10.21203/rs.2.10777/v1

License: (c) (i) This work is licensed under a Creative Commons Attribution 4.0 International License.

Read Full License 


\section{Abstract}

Background Lassa virus (LASV) is a highly prevalent arenavirus that affects two to three million people in West Africa. This rodent borne virus which has serious consequences on the population and hospital staff in endemic areas. In this article, we review prevalence of LASV with a focus on the dynamic and epidemiology of the disease of 1969-2019. What informs on the evolution and the extent of the disease in this at-risk zone in order to prepare response measures in the event of an epidemic. Methods We was conducted a retrospective review through literatures search using the AGORA, PubMed, Science Direct, Scopus, researchgate and Google scholar Database on Lassa fever (LF) from West Africa. A total 34 articles were studied from 11 countries. Studies were categorized by host and country, and meta-analysis conducted to determine pooled prevalence estimates for each category Analysis was done using the metaprop command in STATA version 15 and MetaXL software. Results A total of 18.111 individual samples from 11 countries, described in 34 articles were studied. Meta-analysis of twenty six studies have indicated that the pooled prevalence was $19.0 \%$ [95\% Cl (15.0-23.0\%), I2 = 97.93\%]. There was a high level of heterogeneity between studies; however, the high prevalence of LASV was noted in several countries as Nigeria (12-42\%), followed by Sierra Leone (8-43\%), and then Guinea (9-40\%). Pooled prevalence of LASV for human in studies conducted over the entire review period was $22.0 \%[95 \% \mathrm{Cl}$ (17.0-28.0\%), I2 = 98.0\%]; eighteen studies), while she was 9.0\% [95\% Cl (4.0-15.0\%), I2 = 97.0\%]; eight studies) for Mastomys spp. Conclusion The knowledge of the geographical distribution and epidemiology may have help for disease control efforts and limit the risk of transmission, both locally and internationally. This study is also important in order to guide interventions, public health authorities and inform on the evolution of the disease and its magnitude in the population.

\section{Introduction}

Lassa fever (LF) is acute and viral hemorrhagic fever, which can lead neurological disorders. The pathogenic agent is a virus of the Arenaviridae family and first discovered in 1969 in Nigeria, in two missionary nurses in the town of LF [1]. Since then, this virus, which causes LF, has been reported in many West African countries[2]. LF in this zone is endemic affecting 2 million persons and studies indicated that 300,000 to 500,000 cases are diagnosed and 5000 deaths are noted yearly across[3]. The animal reservoir of infection is the multimammate rat (Mastomys spp.). The majority of human infectious diseases are zoonotic, that is they have a wild or domestic animal origin or reservoir [4]. LF is transmitted to humans when they ingest food contaminated by the feces and urine of Mastomys spp. Once humans are infected, transmission also occurs from human to human through contact with fluid and aerosol secretions in the form of sneezing, sputum, seminal fluid, stool, urine and blood [5]. The World Health Organization listed LF among priority diseases requiring urgent research and development attention [6]. Despite growing interest in LF, our knowledge of its epidemiology and distribution in West Africa is limited. Due to travel of people from endemic areas to non-endemic regions, prevalence of LASV being in addition its air of distribution [7]. However, seroprevalence studies have noted high rate of infections for prevalence of LASV in those Guinean, Nigerian and Sierra Leonean, but also in non-endemic 
areas [8]. Cases of Lasa fever have observed in new area and official incidence reports have seen a substantial increase in the number and geographical extent, which suggests that the true incidence and spatial distribution of the disease may be underestimated [7]. Infectious diseases are significant threats to global human health and economies [9]. Most infections with LF in Africa are asymptomatic, mild or subclinical, the case fatality rate in symptomatic, hospitalized patients ranges from $15-20 \%$, but could be as high as $90 \%$ for pregnant women. Recent studies suggest that outbreaks are largely fueled by independent zoonotic transmission events from infected rodent hosts, whilst approximately $20 \%$ of cases result from secondary human-to-human transmission, typically through super-spreader events in hospital settings [10]. In severe cases, death usually occurs within two weeks following onset of symptoms. Study epidemiology of LF into endemic zone provides important into relevant on the transmission Human to Human or Mastomys spp. to Human and facilitates decision on control strategies. Although there are extensive studies, a systematic review and meta-analysis will realized a general synthesis of different reports on the change in LF is important. As a whole, this set of studies improves our understanding of the geographical distribution of viral hemorrhagic fever. The study was conducted to investigate the prevalence and dynamism for LF in the population in West Africa.

\section{Methods}

We searched in AGORA, PubMed, Science Direct, Scopus, researchgate and Google scholar database. The last search was run on March 31, 2019. To search relevant articles for this study, we used the following keywords "Lassa fever", "prevalence", "prevalence" and "West Africa country (Benin, Burkina Faso, Cape Verde, The Gambia, Ghana, Guinea, Guinea-Bissau, Ivory Coast, Liberia, Mali, Mauritania, the Niger, Nigeria, Senegal, Sierra Leone and Togo)". The key terms were used separately and/ or in combination using Boolean operators like "OR" or "AND". Studies eligible are the ones which reported or allowed to calculate of the prevalence of LF by both Enzyme-Linked Immunosorbent Assay (ELISA) and Reverse Transcription Polymerase Chain Reaction (RT-PCR) or ELISA/RT-PCR on the Human or Mastomys spp. population. The authors agreed that the articles included from the search should meet the following criteria:

(1) the study participants consisted of a population sample of individuals in an endemic area who were chosen on the basis of LF symptoms and confirmed by laboratory test, (2) the study population came from a defined geographical area, and (3) Studies published between 1959, and 2019, in any language were included in the analysis if they explicitly reported the presence of LF.

\section{Data extraction}

From each study, the following information was extracted by 2 independent researchers into records for analysis: countries, location, citation details, study sample, laboratory methods and prevalence of prevalence of LASV as determined by ELISA or PCR. When possible, relevant information was extracted from published abstract. If the data were not in abstract, they were extracted of the text, mostly by 
transformation of numbers to \%. Total number of cases prevalence of LASV out of included patients. The computerized search identified 593 papers, of which 354 excluded after screening of titles. The articles that did not meet the inclusion criteria were rejected, are 165 articles. 74 papers describing ELISA/RT-PCR was used to distinguish prevalence only the data from confirmed result were used. Hence complete information were be extracted from a total of 34 eligible studies.

\section{Quality assessment}

Two researchers independently assessed the articles included using the Quality Assessment of Diagnostic Accuracy Studies (QUADAS-2) tool to assess the methodological quality of eligible studies [11]. The study QUADAS-2 quality criteria are given by Review Manager 5.2, which consists of four domains (patient selection, index test, reference standard, and flow and timing).

\section{Statistical analysis}

Data for analysis were collected into the spreadsheets Excel according to the following categories: study country, biological material, methods used to be identify LASV, number of sick cases and seroepidemiology. Following data extraction and checking, all members of the Literature Review Group were provided with all original data sources and the extraction tables for review. 12 values higher than $25 \%$, $50 \%$, and $75 \%$ are considered evidence of low, moderate, and high heterogeneity among studies, respectively. Software MetaXL was used to calculate the forest plot of LASV infection prevalence in Mastomys spp. and Humans (random-effects model). Sub-group analysis of the studies, which assessed the relationship between LASV prevalence and countries was performed using the Statistical Software Package (STATA) Version 15.0 (StataCorp, College Station, TX, USA). We used the newly developed metaprop command [12].

\section{Result}

In total, 34 studies were selected in 11 countries West Africa among this countries, we are Nigeria $(n=8)$, Guinea $(n=6)$, Mali (3), Ghana $(n=3)$, Ivory Coast $(n=3)$ Sierra Leone $(n=3)$ Benin $(n=2)$, Burkina-Faso $(n=1)$, Liberia $(n=2)$, Togo $(n=2)$ and Senegal $(n=1)$. Data for prevalence of LASV were be extracted from 26 studies whose 8 articles for the Mastomys spp. and 18 on the human with prevalence highest noted respectively 6/25 (24\%) at Mali and 36/84 (43\%) at Sierra Leone. The studies were revealed the prevalence of LASV in order Benin (9.9\%), Guinea (9.15-40.3\%), Ivory Coast (0.7-26\%), Liberia (5.3-14\%), Mali (6.8-33.2\%), Nigeria (12-42\%), Senegal (1.2\%) and Sierra Leone (29-43\%) (Table 1). Cases studies of LASV were be noted in 8 articles mainly in Benin, Burkina-Fasa, Ghana, Nigeria and Togo, but any information on the prevalence of LASV hasn't provided on this reports cases (Table 2).

\section{Prevalence of Lassa virus in Mastomys spp.}


Data from 8 studies from 4 countries were obtained among Mastomys spp. A total number of individual samples was 4442. The prevalence of LASV in Mastomys spp. varied from $0.7 \%$ to $24.00 \%$. The random effect model used in the meta-analysis (Fig. 1) gave an overall estimated prevalence of $9.0 \%$ (95\% confidence interval $[\mathrm{Cl}]$ 4.0-15.0\%). The result of heterogeneity was also $97.0 \%$ (95\% $\mathrm{Cl} 96.10-98.13 \%)$ for the degree of inconsistency.

\section{Prevalence of Lassa virus in Human}

Data from 18 studies from 8 countries were obtained among Human. A total number of individual samples was 13653 . The prevalence of LASV in Human varied from $5.3 \%$ to $40.3 \%$. The random effect model used in the meta-analysis (Fig. 2) gave an overall estimated prevalence of $22.0 \%$ ( $95 \%$ confidence interval [Cl] 17.0-28.0\%). The result of heterogeneity was also $98.0 \%$ (95\% $\mathrm{Cl} 97.77-98.53 \%)$ for the degree of inconsistency.

\section{Subgroup analyses}

\section{Summary statistics of the meta-analysis prevalence of Lassa virus among Human and Mastomys spp. in West Africa}

This meta-analysis was conducted to identify the pooled prevalence of LASV in countries (West Africa) using the available published studies. Table 3 shows the results of subgroup analyses stratified by the country. Due to the high heterogeneity among studies within most subgroups, pooled prevalence for each subgroup were calculated using the random-effects model. On stratification by country, the prevalence at Guinea and Nigeria was estimated respectively $19 \%(95 \% \mathrm{Cl} 12.0-25.0 \%, \mathrm{p}<0.001)$ and $20 \%(95 \% \mathrm{Cl} 15.0-$ $24.0 \%, \mathrm{p}<0.001)$. The high Heterogeneity was noted also at Guinea $(12=97.93 \%)$ and Nigeria $(12=$ $92.86 \%)$. This Meta-analysis included 26 studies where the overall pooled prevalence of LASV was estimated $19 \%(95 \% \mathrm{Cl} 15-23 \%, \mathrm{p}<0.001)$ with the heterogeneity of $98.99 \%$ (Fig. 3)

\section{Dynamics of Lassa virus in West Africa, 1969-2019}

These results give an overview of the dynamics of LASV in 11 West African countries from 1969-2019. A total of 1811 samples were examined and 3166 were found to be positive in the 34 articles that were the subject of this study. Among the studies conducted from 1969-1979, we noted 3 cases of LF in Nigeria. From $1979-1989$ a prevalence of $20.57 \%$ (1140/5547) was noted with 684 positive sample in Sierra Leone, 357 Nigeria, 98 Liberia and 1 Burkina Faso. The work showed a prevalence of 18.88\% (820/4343) from 1989-1999 with 738 cases in Guinea, 68 in Nigeria and 14 in Senegal. The same finding was also made from 1999-2009 with a prevalence of 12.95\% (655/5059) distributed in 4 countries namely Benin 
(9), Guinea (532), Ivory Coast, (47) and Nigeria (67). ). In the period 2009-2019 we had a prevalence of $17.53 \%$ (548/3159) in 8 countries Benin (1), Ghana (6), Ivory Coast (4), Liberia (14), Mali (240), Sierra Leone (40), Nigeria (238) and Togo (5) (Fig. 4).

\section{Discussion}

This article present prevalence of LASV for the areas endemic and provide an important baseline for guiding LF surveillance. LASV was discovered in Nigeria 1969, but this virus was confirmed later in other countries like Guinea (9-40\%), Liberia (5-14\%) and Sierra Leone (8-43\%) where highest infection was be noted. In bordering countries cases of the LF were declared out Nigeria, within on the population, particularly in Benin, Mali, Cote d'Ivoire, Ghana, Burkina Faso and Togo. The findings of Meta-analysis were showed that the overall prevalence of LASV was $19 \%(95 \% \mathrm{Cl} 15-23 \%, \mathrm{p}<0.001)$. This indicates, despite substantial heterogeneity, West Africa remain a endemic area where 300000 to 500000 cases of LF were estimated annually [45]. The predominant prevalence of LF in West Africa was noted in Sierra Leone, Liberia, Guinea et Nigeria because may be due to relative the culinary attitude of the population [8]. This prevalence might be related partly to population movements during the civil unrest some countries in West Africa in the 1960 especially in Sierra Leone. Despite the presence of the reservoir host of this virus in other parts of the world, it is only in West Africa that it is rife, which was due to favorable climatic factors that favor the maintenance and development of the virus in West Africa [46]. According to the works Manning et al. [47], the prevalence of LF is being highest in forested regions of West Africa. This is likely due to the fact that forested parts of endemic regions harbor large populations of the reservoir rodents (Mastomys spp.) capable of transmitting the virus to the human population. This is the case of Sierra Leone and Guinea where high prevalence is observed in the forest regions. Which could explain the presence of LF cases in other West African countries. ECDC, [7] reports have shown that $80 \%$ of FL cases are asymptomatic. Symptoms of LF are varied and non-specific, making clinical diagnosis often difficult, especially early in the course of the disease. Most LASV human infections are asymptomatic and Clinical recognition can be challenging due to the similar symptoms as such general weakness, muscle aches, fever, nausea, vomiting, sore throat, pharyngitis, dry cough, chest and abdominal pain, which such as are known to the clinical sign of malaria by the population, could be responsible of distribution [35]. More research on humans and animal reservoirs interact, as well as how the disease is transmitted within these populations, is needed to understand the distribution LF. The meta-analysis of LASV in the rat population Mastomys spp. showed a higher prevalence of LASV, with the overall pooled prevalence of $9.0 \%$ (95\% confidence interval $[\mathrm{Cl}]$ 4.0-15.0\%). It maintains the zoonotic cycle of $\mathrm{LF}$ and is responsible for reinfection when conditions are favorable. The works realized on evolutionary history of LF were showed that Mastomys natalensis infected is the main source of human infection [48]. Rodent-to-human transmission was possible contact with the excreta, urine of infected rodents. They assure also dissemination of LASV in environment and food contaminate. The result of our study is similar to that reported by Fichet-Calvet et al. [49] who were showed that infected Mastomys spp. are responsible for spatial distribution of LF in endemic. It has been also observed that other rodent species may also be hosts for LASV as the African wood mouse, Hylomyscus pamfi [50]. The prevalence of LASV in the Mastomys natalensis, found in the 
southern Mali near the border of Ivory Coast was 0 to 52\% [26]. The presence of LASV was noted in Rattus rattus, Mastomys musculus and Mastomys natalensis. But Mastomys natalensis recorded the highest LASV among rodents trapped in Edo (87\%), Delta (50\%) and Bayelsa (11\%) States respectively [51]. Human infectious diseases are a significant threat to global human health and with the majority of infectious diseases having a zoonotic. Recent investigations have found that LF is more widely distributed throughout the Wooded Savanna in West Africa [27]. In contrary to the study carried out by Richmond, Baglole [52], which is showed that LF was abundant in urban areas to poor sanitation and overcrowding. The meta-analysis of LASV infection prevalence in Human found a higher prevalence of LASV, with the overall pooled prevalence of $22.0 \%$ (95\% confidence interval [CI] 17.0-28.0\%), evidence for the endemicity of LF disease in West Africa. The LF proportion is partly due to underdevelopment, this disease occurs in the poorest areas where, population with poor sanitation and/or crowded living conditions. But also misunderstanding of the most basic rules regarding the transmission of LF, which is mainly transmitted through contact with infected rodents and, to a lesser extent, person-to-person contact. Which justifies the high prevalence obtained in rural areas, poor and illiterate [53]. These findings corroborate the works realized by Richmond and Baglole [52], who showed that the prevalence of LF was estimated at Sierra Leone (50.2\%), Guinea (55\%) and Nigeria (21\%). A typical example of transmission of LASV is the practice of funeral rites and ancestral burials that have been established. Funeral practices and burials in West Africa were associated with an unusually high risk of the disease. For example, in Liberia and Sierra Leone, some mourners bathe or anoint others with water from the washing of deceased bodies. Some people sleep near the highly infectious deceased bodies for several nights, believing that this allowed a transfer of powers. All of these reasons explain this high prevalence of LASV in the human population. LF outbreaks mostly occur in rural areas and during the dry season [10]. Hospitals in endemic areas are also sources of infection and propagation of LASV, according to Dahmane et al. [37], the prevalence of LF in the children and women with obstetric conditions in a rural district hospital in Sierra Leone was $43 \%$. The role of human-to-human transmission in the distribution of the disease is very important healthcare workers were exposed LF infection [29]. Most the hospitals in the endemic areas of LF in West Africa have not a capacity to perform LASV diagnostics. Case identification and management solely relies on non-specific clinical criteria [34], which would be the cause of this prevalence of LF noted among health workers. Many serologic assays (ELISA) based on the identification of antigens and antibodies (Immunoglobulin M "IgM" / Immunoglobulin G "IgG") and reverse transcription polymerase chain reaction (RT-PCR), were used for LASV confirmation. RT-PCR is a rapid molecular tool for detection of LASV, this test is effective but present these limits today because of the genetic diversity of the strain of LASV. According to the reports done by ECDC [6] on Diagnosis of LF. The serologic testing for IgM and IgG antibodies demonstrated easy use in the field without the need for expensive equipment [22]. The results of our research have shown a resurgence of the LF in the period 2009-2019 in West Africa and this may continue for the coming years. Causes of Resurgence of LF have been attributed the lacks early warning system and rapid response, once one case is suspected [54]. Health centers in endemic areas lack even the minimum, the total absence of reliable LASV point of care and field diagnostic tools for early detection and rapid molecular case confirmation. For prevent and respond promptly facing of LF, it is necessary to strengthen local, regional epidemiologic surveillance and integrating community "One 
Health" and regularly the level of health staff to the base and especially in the areas at risk on the information relating to the LF. However, our results should be interpreted with caution given the limited number of studies included in each country.

\section{Conclusion}

The present systematic review and Meta-analysis was showed that the prevalence for LASV is high in West Africa. The prevalence of LASV varies across different regions of the country and from one country to another. This calls the Ministry of Health and all the actors in the community "One Health" and of surveillance system for detection and response to these LASV outbreaks to avoid a epidemic. The information obtained from this systematic review and Meta-analysis may improve knowledge on the dynamic and epidemiology of LASV in West Africa and will certainly guide the measures to be taken in the fight against LF for the years to come.

\section{Abbreviations}

Cl: Confidence interval, ECDC: European Centre for Disease Prevention and Control, ELISA: Enzyme-Linked Immunosorbent Assay, ES: Error Standard, IgG: Immunoglobulin G, IgM: Immunoglobulin M, LASV: Lassa virus, LF: Lassa fever, Prev: Prevalence, QUADAS: Quality Assessment of Diagnostic Accuracy Studies, RTPCR: Reverse Transcription Polymerase Chain Reaction.

\section{Declarations}

\section{Acknowledgements}

We thank Communicable Disease Research Unit (URMaT), University of Abomey-Calavi, Cotonou, Benin.

\section{Competing interests}

The authors declare that they have no competing interests.

\section{Funding}

There was no any funding or sponsoring organization for this paper.

\section{Authors' contributions}

REY was the principal investigator who contributed to origin, the idea and design of the study, and acted as corresponding author. ID and EYS conducted the literature search and systematic review. REY and 
ARKW performed the meta-analysis. REY, ARKW, JA, RO, AD and SF contributed to drafting the manuscript. All authors read and approved the final manuscript.

\section{Consent for publication}

Not applicable.

\section{Ethics approval and consent to participate}

Not applicable.

\section{Authors' Affiliations}

a. Communicable Disease Research Unit (URMaT), University of Abomey-Calavi, Cotonou, Benin, 01 Po. Box: 2009 Cotonou, Benin.

b. Inter-State School of Veterinary Sciences and Medicine of Dakar, Po. Box 5077 Dakar - Senegal.

c. Department of Biology, Faculty of Sciences, Gamal Abdel Nasser University of Conakry, 01 Po. Box: 1147 Conakry, Guinea.

d. University of Abomey-Calavi (UAC), Faculty of Humanities and Social Sciences, 01 Po. Box: 526 Cotonou, Benin.

e. University of Abomey-Calavi (UAC), Faculty of Health Sciences, School of Pharmacy, 01 Po. Box: 526 Cotonou, Benin.

f. National University of Agriculture, Po. Box: 43 Ketou, Benin.

\section{References}

1. Frame JD, Baldwin Jr JM, Gocke DJ, Troup JM. Lassa fever, a new virus disease of man from West Africa. Am J Trop Med Hyg. 1970;19:670-676.

2. Mylne AQ, Pigott DM, Longbottom J, Shearer F, Duda KA, Messina JP, et al. Mapping the zoonotic niche of Lassa fever in Africa. Trans R Soc Trop Med Hyg. 2015;109:483-492.

3. Sogoba N, Feldmann H, Safronetz D. Lassa fever in West Africa: evidence for an expanded region of endemicity. Zoonoses Public Health. 2012;59:43-47.

4. Han BA, Schmidt JP, Bowden SE, Drake JM. Rodent reservoirs of future zoonotic diseases. Proc Natl Acad Sci. 2015;112:7039-7044. 
5. Bonwitt J, Sáez AM, Lamin J, Ansumana R, Dawson M, Buanie J, et al. At home with Mastomys and Rattus: human-rodent interactions and potential for primary transmission of Lassa virus in domestic spaces. Am J Trop Med Hyg. 2017;96:935-943.

6. Mehand MS, Al Shorbaji F, Millett P, Murgue B. The WHO R\&D Blueprint: 2018 review of emerging infectious diseases requiring urgent research and development efforts. Antiviral Res. 2018;

7. ECDC. European Centre for Disease Prevention and Control (ECDC). Lassa fever in Nigeria, Benin, Togo - Recherche Google. 2016.

8. Brosh-Nissimov T. Lassa fever: another threat from West Africa. Disaster Mil Med. 2016;2:8.

9. Shah N, Kuriansky J. The impact and trauma for healthcare workers facing the Ebola epidemic. Psychosoc Asp Deadly Epidemic What Ebola Has Taught Us Holist Heal ABC-CLIO LLC St Barbara Calif. 2016;91-109.

10. Shehu NY, Gomerep SS, Isa SE, Iraoyah KO, Mafuka J, Bitrus N, et al. Lassa Fever 2016 Outbreak in Plateau State, Nigeria-The Changing Epidemiology and Clinical Presentation. Front Public Health. 2018;6.

11. Whiting PF, Rutjes AW, Westwood ME, Mallett S, Deeks JJ, Reitsma JB, et al. QUADAS-2: a revised tool for the quality assessment of diagnostic accuracy studies. Ann Intern Med. 2011;155:529-536.

12. Nyaga VN, Arbyn M, Aerts M. Metaprop: a Stata command to perform meta-analysis of binomial data. Arch Public Health. 2014;72:39.

13. Emmerich P, Günther S, Schmitz H. Strain-specific antibody response to Lassa virus in the local population of west Africa. J Clin Virol. 2008;42:40-44.

14. Fichet-Calvet E, Lecompte E, Koivogui L, Soropogui B, Doré A, Kourouma F, et al. Fluctuation of abundance and Lassa virus prevalence in Mastomys natalensis in Guinea, West Africa. Vector-Borne Zoonotic Dis. 2007;7:119-128.

15. Demby AH, Inapogui A, Kargbo K, Koninga J, Kourouma K, Kanu J, et al. Lassa fever in Guinea: II. Distribution and prevalence of Lassa virus infection in small mammals. Vector Borne Zoonotic Dis. $2001 ; 1: 283-297$.

16. Lecompte E, Fichet-Calvet E, Daffis S, Koulémou K, Sylla O, Kourouma F, et al. Mastomys natalensis and lassa fever, West Africa. Emerg Infect Dis. 2006;12:1971.

17. Kernéis S, Koivogui L, Magassouba N, Koulemou K, Lewis R, Aplogan A, et al. Prevalence and risk factors of Lassa seropositivity in inhabitants of the forest region of Guinea: a cross-sectional study. PLoS Negl Trop Dis. 2009;3:e548. 
18. Klempa B, Koulemou K, Auste B, Emmerich P, Thomé-Bolduan C, Günther S, et al. Seroepidemiological study reveals regional co-occurrence of Lassa- and Hantavirus antibodies in Upper Guinea, West Africa. Trop Med Int Health TM IH. 2013;18:366-71.

19. Lukashevich IS, Clegg JCS, Sidibe K. Lassa virus activity in Guinea: Distribution of human antiviral antibody defined using enzyme-linked immunosorbent assay with recombinant antigen. J Med Virol. 1993;40:210-217.

20. Coulibaly-N'Golo D, Allali B, Kouassi SK, Fichet-Calvet E, Becker-Ziaja B, Rieger T, et al. Novel arenavirus sequences in Hylomyscus sp. and Mus (Nannomys) setulosus from Côte d'Ivoire: implications for evolution of arenaviruses in Africa. PloS One. 2011;6:e20893.

21. Kouadio L, Nowak K, Akoua-Koffı C, Weiss S, Allali BK, Witkowski PT, et al. Lassa virus in multimammate rats, Côte d'Ivoire, 2013. Emerg Infect Dis. 2015;21:1481.

22. Akoua-Koffi C, Ter JM, Legros D, Akran V, Aidara M, Nahounou N, et al. Detection of anti-Lassa antibodies in the Western Forest area of the Ivory Coast. Med Trop Rev Corps Sante Colon. 2006;66:465468.

23. Yalley-Ogunro JE, Frame JD, Hanson AP. Endemic Lassa fever in Liberia. VI. Village serological surveys for evidence of Lassa virus activity in Lofa County, Liberia. Trans R Soc Trop Med Hyg. 1984;78:764-770.

24. Hamblion EL, Raftery P, Wendland A, Dweh E, Williams GS, George RNC, et al. The challenges of detecting and responding to a Lassa fever outbreak in an Ebola-affected setting. Int $\mathrm{J}$ Infect Dis. 2018;66:65-73.

25. Safronetz D, Lopez JE, Sogoba N, Traore SF, Raffel SJ, Fischer ER, et al. Detection of Lassa virus, Mali. Emerg Infect Dis. 2010;16:1123.

26. Safronetz D, Sogoba N, Lopez JE, Maiga O, Dahlstrom E, Zivcec M, et al. Geographic distribution and genetic characterization of Lassa virus in sub-Saharan Mali. PLoS Negl Trop Dis. 2013;7:e2582.

27. Sogoba N, Rosenke K, Adjemian J, Diawara SI, Maiga O, Keita M, et al. Lassa virus seroprevalence in sibirilia commune, bougouni district, southern mali. Emerg Infect Dis. 2016;22:657.

28. Asogun DA, Adomeh DI, Ehimuan J, Odia I, Hass M, Gabriel M, et al. Molecular diagnostics for lassa fever at Irrua specialist teaching hospital, Nigeria: lessons learnt from two years of laboratory operation. PLoS Negl Trop Dis. 2012;6:e1839.

29. Ehichioya DU, Asogun DA, Ehimuan J, Okokhere PO, Pahlmann M, Ölschläger S, et al. Hospital-based surveillance for Lassa fever in Edo State, Nigeria, 2005-2008. Trop Med Int Health. 2012;17:1001-1004. 
30. Bajani MD, Tomori O, Rollin PE, Harry TO, Bukbuk ND, Wilson L, et al. A survey for antibodies to Lassa virus among health workers in Nigeria. Trans R Soc Trop Med Hyg. 1997;91:379-381.

31. Oloniniyi OK, Unigwe US, Okada S, Kimura M, Koyano S, Miyazaki Y, et al. Genetic characterization of Lassa virus strains isolated from 2012 to 2016 in southeastern Nigeria. PLoS Negl Trop Dis. 2018;12:e0006971.

32. Tomori O, Fabiyi A, Sorungbe A, Smith A, McCormick JB. Viral hemorrhagic fever antibodies in Nigerian populations. Am J Trop Med Hyg. 1988;38:407-410.

33. Bukbuk DN, Fukushi S, Tani H, Yoshikawa T, Taniguchi S, Iha K, et al. Development and validation of serological assays for viral hemorrhagic fevers and determination of the prevalence of Rift Valley fever in Borno State, Nigeria. Trans R Soc Trop Med Hyg. 2014;108:768-773.

34. Saluzzo JF, Adam F, McCormick JB, Digoutte JP. Lassa fever virus in Senegal. J Infect Dis. 1988;157:605-605.

35. McCormick JB, Webb PA, Krebs JW, Johnson KM, Smith ES. A prospective study of the epidemiology and ecology of Lassa fever. J Infect Dis. 1987;155:437-444.

36. Cummins D, McCormick JB, Bennett D, Samba JA, Farrar B, Machin SJ, et al. Acute sensorineural deafness in Lassa fever. Jama. 1990;264:2093-2096.

37. Dahmane A, van Griensven J, Van Herp M, Van den Bergh R, Nzomukunda Y, Prior J, et al. Constraints in the diagnosis and treatment of Lassa Fever and the effect on mortality in hospitalized children and women with obstetric conditions in a rural district hospital in Sierra Leone. 2014 [cited 2019 Apr 23]; Available from: https://fieldresearch.msf.org/handle/10144/315033

38. Attinsounon CA, Ibara BRO, Alassani A, Adé S, Saké K, Kakaï CG, et al. Report of a fatal case of Lassa fever in Parakou in 2018: clinical, therapeutic and diagnostic aspects. BMC Infect Dis. 2018;18:667.

39. van der Heide RM. A patient with Lassa fever from Upper Volta, diagnosed in the Netherlands. Ned Tidjschrift Voor Geneeskd. 1982;126:566-569.

40. Kyei NN, Abilba MM, Kwawu FK, Agbenohevi PG, Bonney JH, Agbemaple TK, et al. Imported Lassa fever: a report of 2 cases in Ghana. BMC Infect Dis. 2015;15:217.

41. Bonney JH, Nyarko EO, Ohene S-A, Amankwa J, Ametepi RK, Nimo-Paintsil SC, et al. Molecular confirmation of Lassa fever imported into Ghana. Afr J Lab Med. 2016;5:1-6.

42. Dzotsi EK, Ohene SA, Asiedu-Bekoe F, Amankwa J, Sarkodie B, Adjabeng M, et al. The first cases of Lassa fever in Ghana. Ghana Med J. 2012;46:166. 
43. Raabe VN, Kann G, Ribner BS, Morales A, Varkey JB, Mehta AK, et al. Favipiravir and ribavirin treatment of epidemiologically linked cases of Lassa fever. Clin Infect Dis. 2017;65:855-859.

44. Whitmer SL, Strecker T, Cadar D, Dienes H-P, Faber K, Patel K, et al. New lineage of Lassa virus, Togo, 2016. Emerg Infect Dis. 2018;24:599.

45. Ogbu O, Ajuluchukwu E, Uneke CJ. Lassa fever in West African sub-region: an overview. J Vector Borne Dis. 2007;44:1.

46. Fichet-Calvet E, Rogers DJ. Risk maps of Lassa fever in West Africa. PLoS Negl Trop Dis. 2009;3:e388.

47. Manning JT, Forrester N, Paessler S. Lassa virus isolates from Mali and the Ivory Coast represent an emerging fifth lineage. Front Microbiol. 2015; 6: 1037. 2015.

48. Lalis A, Leblois R, Lecompte E, Denys C, ter Meulen J, Wirth T. The impact of human conflict on the genetics of Mastomys natalensis and Lassa virus in West Africa. PLoS One. 2012;7:e37068.

49. Fichet-Calvet E, Ölschläger S, Strecker T, Koivogui L, Becker-Ziaja B, Camara AB, et al. Spatial and temporal evolution of Lassa virus in the natural host population in Upper Guinea. Sci Rep. 2016;6:21977.

50. Olayemi A, Cadar D, Magassouba N, Obadare A, Kourouma F, Oyeyiola A, et al. New hosts of the Lassa virus. Sci Rep. 2016;6:25280.

51. Agbonlahor DE, Erah A, Agba IM, Oviasogie FE, Ehiaghe AF, Wankasi M, et al. Prevalence of Lassa virus among rodents trapped in three South-South States of Nigeria. J Vector Borne Dis. 2017;54:146.

52. Richmond JK, Baglole DJ. Lassa fever: epidemiology, clinical features, and social consequences. Bmj. 2003;327:1271-1275.

53. Hallam HJ, Hallam S, Rodriguez SE, Barrett AD, Beasley DW, Chua A, et al. Baseline mapping of Lassa fever virology, epidemiology and vaccine research and development. NPJ Vaccines. 2018;3:11.

54. Tambo E, Adetunde OT, Olalubi OA. Re-emerging Lassa fever outbreaks in Nigeria: Re-enforcing "One Health" community surveillance and emergency response practice. Infect Dis Poverty. 2018;7:37.

\section{Tables}

Table1: Characteristics of included studies for meta-analysis of Lassa virus infection 


\begin{tabular}{|c|c|c|c|c|c|c|}
\hline Country & Authors & $\begin{array}{l}\text { Year of } \\
\text { study }\end{array}$ & Hosts & Method & $\begin{array}{l}\text { Sample } \\
\text { size }\end{array}$ & $\begin{array}{c}\text { Prevalence } \\
(\%)\end{array}$ \\
\hline Benin & Emmerich et al., 2008 [13] & 2008 & Human & ELISA & 88 & $9(9.9)$ \\
\hline Guinea & $\begin{array}{l}\text { Fichet-Calvet et al., } 2007 \\
{[14]}\end{array}$ & $2003-2004$ & $\begin{array}{l}\text { Mastomys } \\
\text { spp }\end{array}$ & RT-PCR & 553 & $80(14.5)$ \\
\hline Guinea & Demby et al., 2001 [15] & 2001 & $\begin{array}{l}\text { Mastomys } \\
\text { spp }\end{array}$ & ELISA & 884 & $142(16)$ \\
\hline Guinea & Lecompte et al., 2006 [16] & $2002-2005$ & $\begin{array}{l}\text { Mastomys } \\
\text { spp }\end{array}$ & RT-PCR & 1049 & $96(9.15)$ \\
\hline Guinea & Kerneis et al., 2009 [17] & 2000 & Human & ELISA & 977 & $112(11.46)$ \\
\hline Guinea & Klempa et al., 2013 [18] & 2004 & Human & ELISA & 253 & $102(40.3)$ \\
\hline Guinea & Lukashevich et al., 1993 [19] & 1990-1992 & Human & ELISA & 3126 & $738(23.6)$ \\
\hline $\begin{array}{l}\text { Ivory } \\
\text { Coast }\end{array}$ & $\begin{array}{l}\text { Coulibaly-N'Golo et al., } 2011 \\
{[20]}\end{array}$ & $2003-2005$ & $\begin{array}{l}\text { Mastomys } \\
\text { spp }\end{array}$ & RT-PCR & 737 & $5(0.7)$ \\
\hline $\begin{array}{l}\text { Ivory } \\
\text { Coast }\end{array}$ & Kouadio et al., 2015 [21] & 2013 & $\begin{array}{l}\text { Mastomys } \\
\text { spp }\end{array}$ & RT-PCR & 18 & $4(22.2)$ \\
\hline $\begin{array}{l}\text { Ivory } \\
\text { Coast }\end{array}$ & Akoua-Coffi et al., 2006 [22] & 2000 & Human & ELISA & 161 & $42(26)$ \\
\hline Liberia & $\begin{array}{l}\text { Yalley-Ogunr et al., } 1984 \\
\text { [23] }\end{array}$ & 1980-1982 & Human & ELISA & 1848 & $98(5.3)$ \\
\hline Liberia & Hamblion et., 2018 [24] & 2016 & Human & $\begin{array}{l}\text { RT- } \\
\text { PCR/ELISA }\end{array}$ & 53 & $14(14)$ \\
\hline Mali & Safronetz et al., 2010 [25] & 2009 & $\begin{array}{l}\text { Mastomys } \\
\text { spp }\end{array}$ & RT-PCR & 25 & $6(24)$ \\
\hline Mali & Safronetz et al., 2013 [26] & $2007-2012$ & $\begin{array}{l}\text { Mastomys } \\
\text { spp }\end{array}$ & $\begin{array}{l}\text { RT- } \\
\text { PCR/ELISA }\end{array}$ & 511 & $35(6.8)$ \\
\hline Mali & Sogoba et al., 2016 [27] & 2015 & Human & ELISA & 600 & $199(33.2)$ \\
\hline Nigeria & Asogun et al., 2012 [28] & $2009-2010$ & Human & RT-PCR & 1650 & $198(12)$ \\
\hline Nigeria & Ehichioya et al., 2012 [29] & $2005-2008$ & Human & $\begin{array}{l}\text { RT- } \\
\text { PCR/ELISA }\end{array}$ & 60 & $25(42)$ \\
\hline Nigeria & Bajani et al., 1997 [30] & $1992-1993$ & Human & ELISA & 552 & $68(12.3)$ \\
\hline Nigeria & Oloniniyi et al., 2018 [31] & $2012-2016$ & Human & RT-PCR & 123 & $29(23.5)$ \\
\hline Nigeria & Tomori et al., 1988 [32] & 1985 & Human & ELISA & 1677 & $357(21.3)$ \\
\hline Nigeria & Shehu et al., 2018 [10] & 2016 & Human & RT-PCR & 34 & $11(32.3)$ \\
\hline Nigeria & Bukbuk et al., 2014 [33] & $2003-2004$ & Human & RT-PCR & 297 & $42(14.1)$ \\
\hline Senegal & Saluzzo et al., 1998 [34] & 1998 & $\begin{array}{l}\text { Mastomys } \\
\text { spp }\end{array}$ & ELISA & 665 & $14(1.2)$ \\
\hline $\begin{array}{l}\text { Sierra } \\
\text { Leone }\end{array}$ & McCormick et al., 1987 [35] & 1983 & Human & ELISA & 2021 & $684(33.84)$ \\
\hline $\begin{array}{l}\text { Sierra } \\
\text { Leone }\end{array}$ & Cummins et al., 1990 [36] & 2018 & Human & RT-PCR & 49 & $4(8.16)$ \\
\hline $\begin{array}{l}\text { Sierra } \\
\text { Leone }\end{array}$ & Dahmane et al., 2014 [37] & $2011-2012$ & Human & ELISA & 84 & $36(43)$ \\
\hline
\end{tabular}


Table 2: Cases reports of Lassa virus infection

\begin{tabular}{|c|c|c|c|c|c|}
\hline Country & Authors & Year of study & Hosts & Method & Cases of LF \\
\hline Benin & Attinsounon et al., 2018 [38] & 2018 & Human & RT-PCR & 1 \\
\hline Burkina-Fasa & Van Der Heide et al., 1982 [39] & 1982 & Human & ELISA & 1 \\
\hline Ghana & Kyei et al., 2015 [40] & 2015 & Human & RT-PCR & 2 \\
\hline Ghana & Bonney et al., 2016[41] & 2013 & Human & RT-PCR & 2 \\
\hline Ghana & Dzotsi et al., 2012 [42] & 2011 & Human & RT-PCR & 2 \\
\hline Nigeria & Frame et al., 1970[1] & 1969 & Human & ELISA & 3 \\
\hline Togo & Raabe et al., 2017[43] & 2016 & Human & RT-PCR & 2 \\
\hline Togo & Whitmer et., 2018 [44] & 2016 & Human & RT-PCR & 3 \\
\hline
\end{tabular}

\section{Figures}

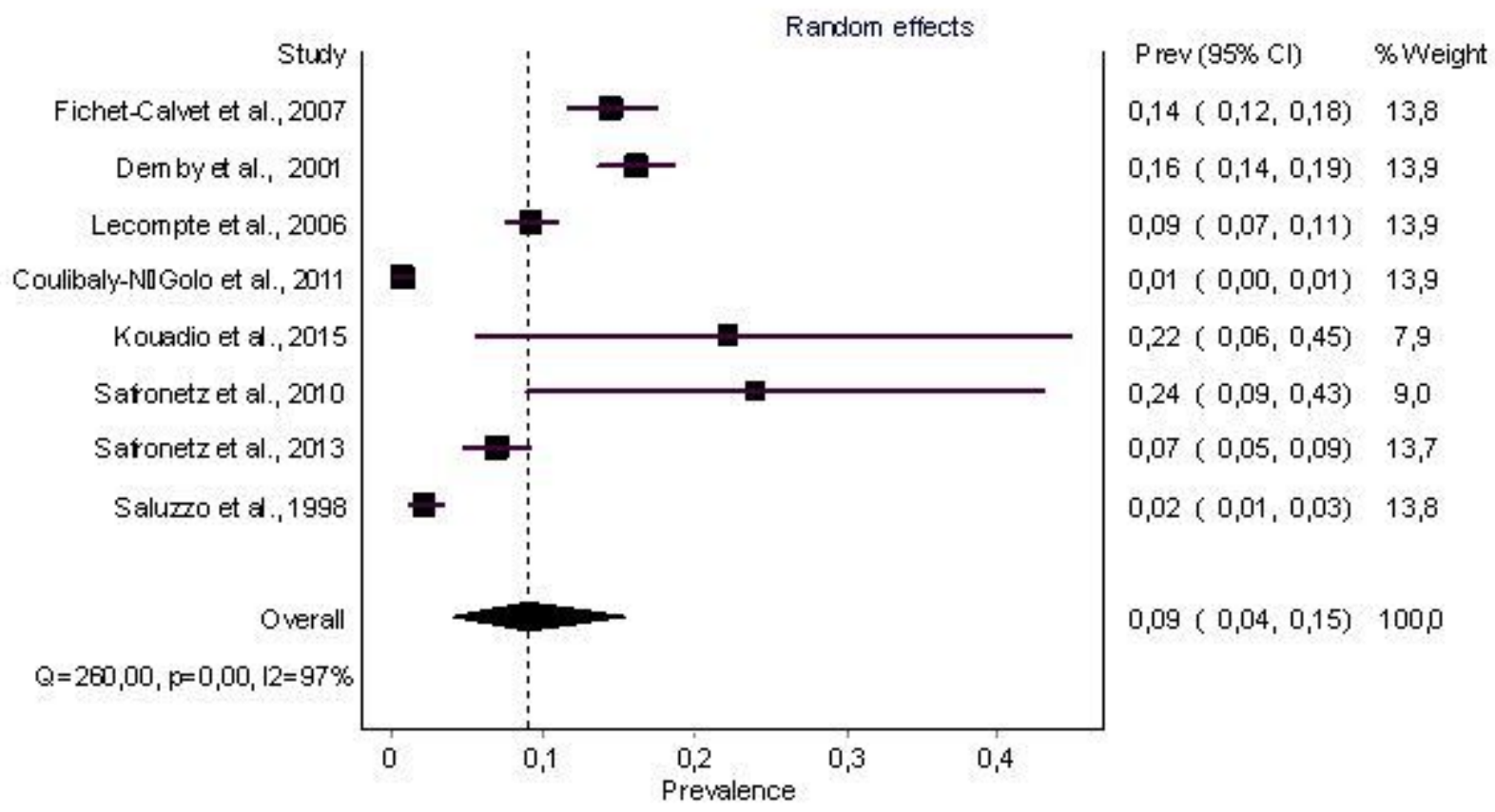

Figure 1 
Forest plot of Lassa virus infection prevalence in Mastomys spp. (random-effects model).

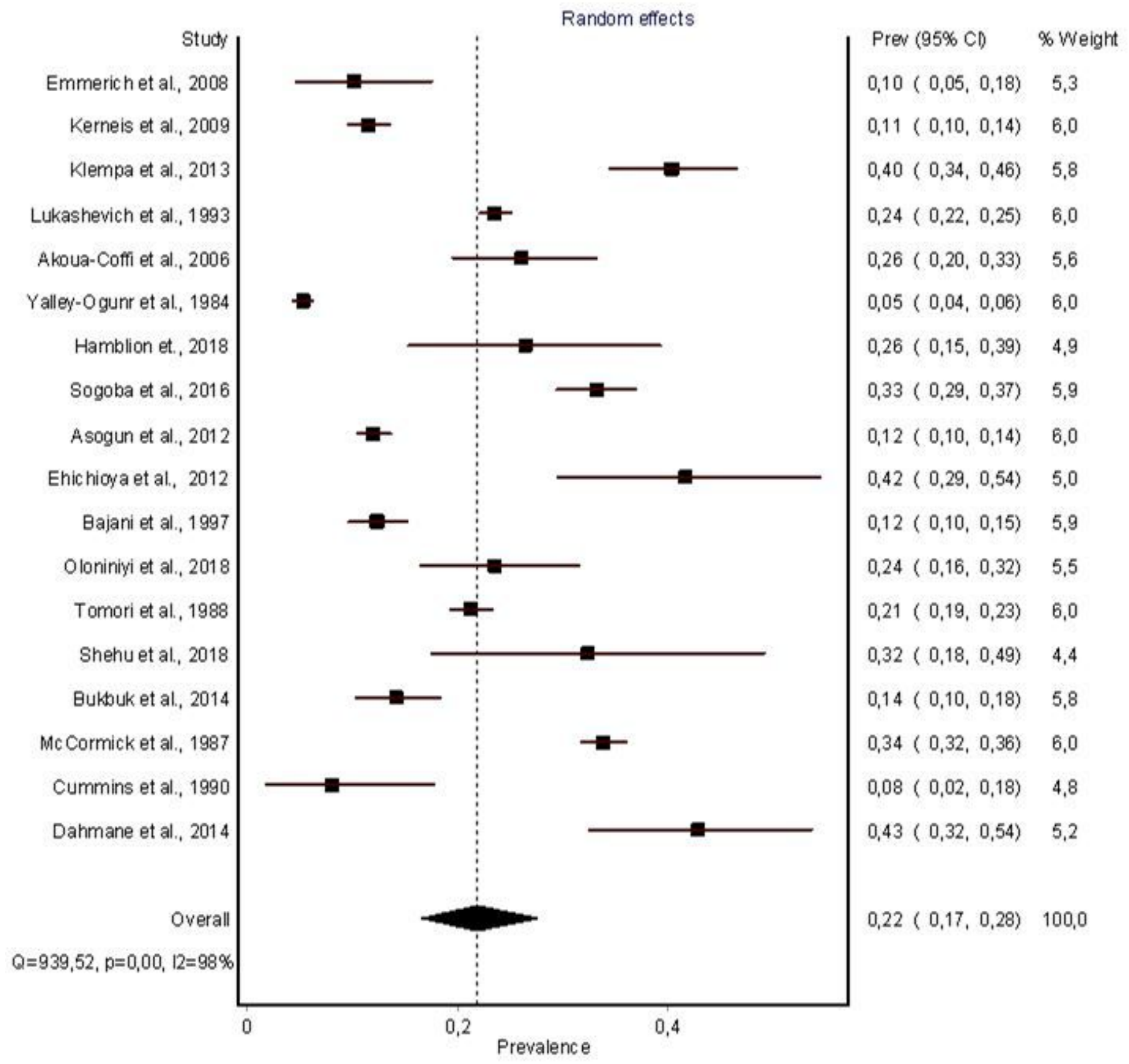

Figure 2

Forest plot of Lassa virus infection prevalence in Human (random-effects model). 


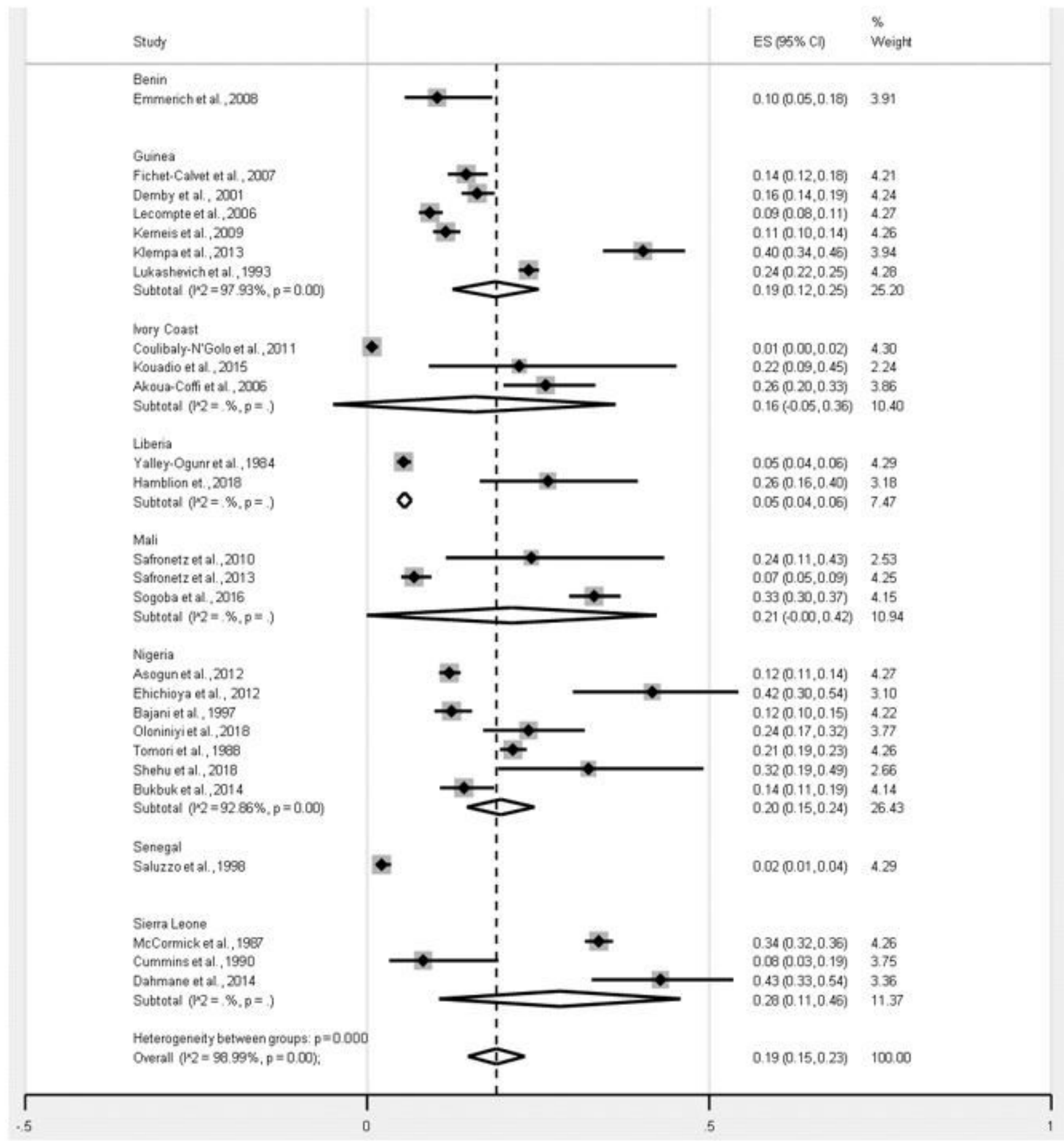

\section{Figure 3}

Forest plot showing stratified meta-analysis of Lassa virus infection prevalence by country estimated by the random effects model (Benin, Guinea, Ivory Coast, Liberia, Mali, Nigeria, Senegal and Sierra Leone) 


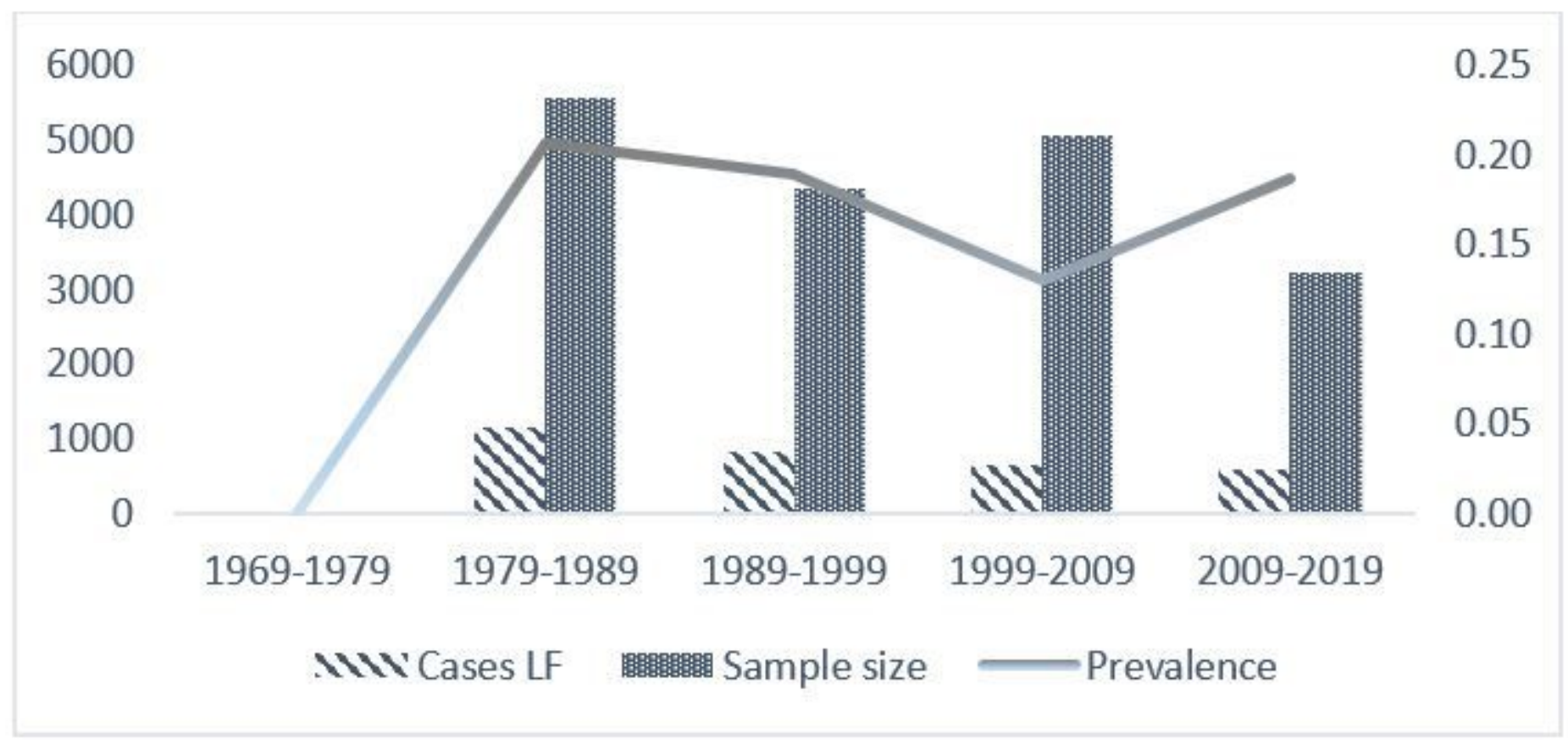

Figure 4

Prevalence of West African LF infection of 1969-2019 


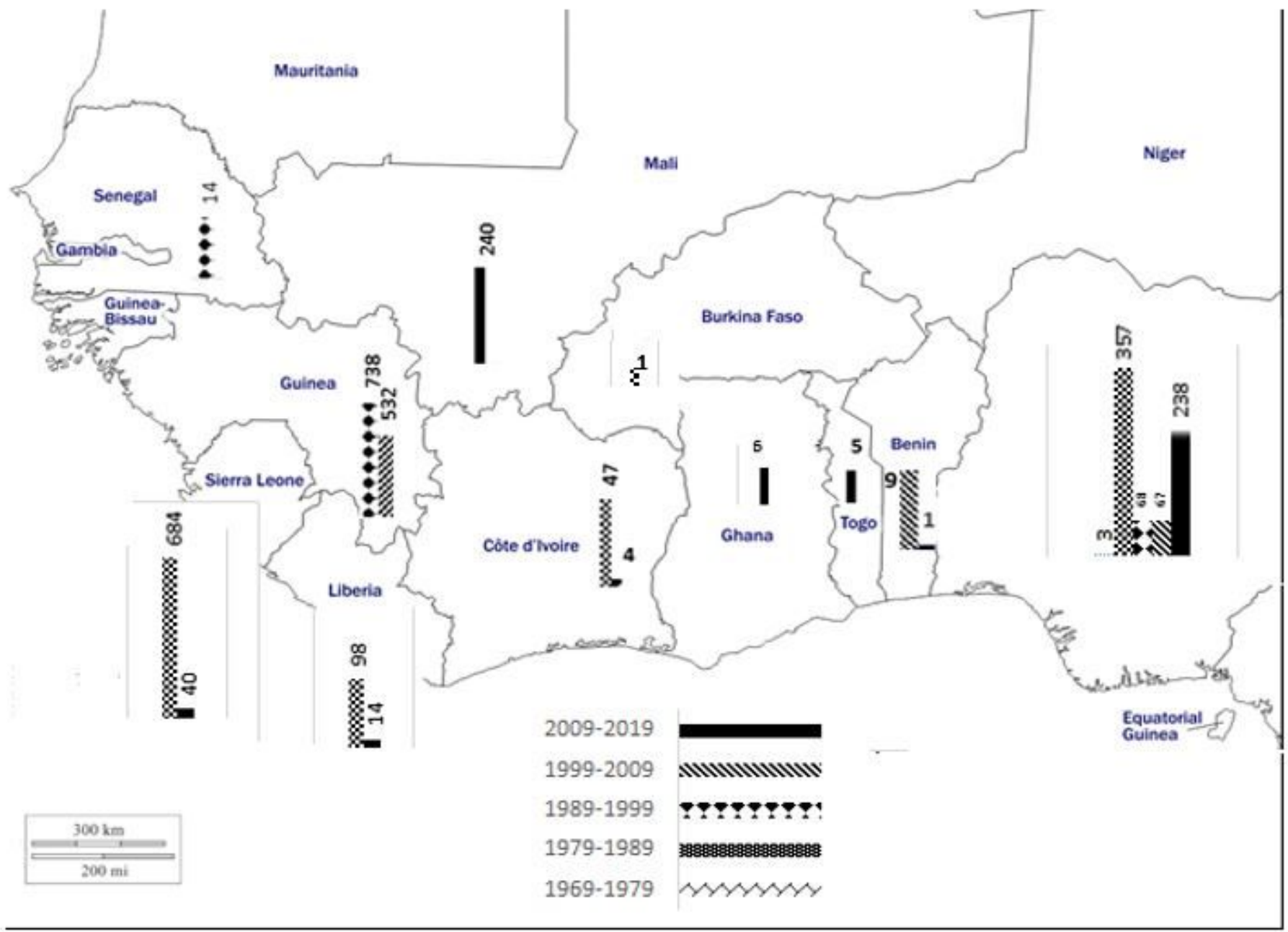

Figure 5

The known distribution and reported history of Lassa virus in West Africa. Histogram on the map represent human and Mastomys spp. LF outbreak reports in West Africa (both suspected and confirmed) from 1969-2019. Histograms represents a sum of cases reported in each country in a given period. 